Naskah diserahkan:08-02-2022, Direvisi: 22-02-2022; Diterima: 24-02-2022

\section{Analisis Word of Mouth, Harga dan Kualitas Pelayanan terhadap Keputusan Mengunjungi Taman Margasatwa Ragunan dan Dampaknya terhadap Kepuasan Wisatawan}

Fajar Adi Prakoso

Program Studi Manajemen, Universitas Muhammadiyah Jakarta

Email Korespondensi: f.adiprakoso@umj.ac.id

\begin{abstract}
ABSTRAK : Pariwisata merupakan sektor yang memiliki kontribusi bagi negara dengan menyerap tenaga kerja yang sangat besar. Berkembangnya industri pariwisata dapat mendorong ekonomi masyarakat, namun belum banyak diberdayakan secara optimal. Di sisi lain, tuntutan akan kualitas pelayanan suatu wisata menjadi hal yang perlu ditingkatkan untuk memberikan kepuasan bagi wisatawan. Penelitian ini bertujuan untuk menguji pengaruh Word of Mouth, harga, dan kualitas pelayanan terhadap kunjungan wisatawan serta untuk mengetahui dampaknya pada kepuasan wisatawan. Penelitian ini menggunakan teknik non-probability dengan sampel berjumlah 60 sampel. Teknik Analisis data menggunakan analisa jalur untuk menguji besarnya kontribusi yang ditujukan oleh koefisien jalur pada setiap diagram jalur dari hubungan kausal variabel $X_{1}, X_{2}, X_{3}$ terhadap $Y_{1}, Y_{2}$.. Hasil penelitian menunjukkan bahwa terdapat pengaruh antara word of mouth terhadap keputusan kunjungan wisatawan, pengaruh harga terhadap keputusan kunjungan wisatawan, sedangkan kualitas layanan terhadap keputusan kunjungan wisatawan memiliki pengaruh pada keputusan kunjungan wisatawan. Pada pengujian Bersama variabel word of mouth, harga, dan kualitas layanan memiliki pengaruh terhadap keputusan kunjungan wisatawan. Sementara itu beberapa variabel bebas seperti word of mouth, harga dan kualitas layanan pada pengujian secara parsial memiliki pengaruh terhadap variabel kepuasan. Pada pengujian berikutnya keputusan kunjungan berpengaruh terhadap kepuasan wisatawan.
\end{abstract}

Kata Kunci: Harga; Kualitas Layanan; Kepuasan; Keputusan Kunjungan; Word of Mouth (WOM)

ABSTRACT: Tourism is a sector that contributes to the country by absorbing a considerable workforce. The development of the tourism industry can encourage the community's economy but has not been optimally empowered. On the other hand, the demand for the quality of tourism services needs to be improved to provide satisfaction for tourists. This study aims to examine the effect of Word of Mouth, price, and service quality on tourist visits and to determine the impact on tourist satisfaction. This study uses a non-probability technique with a sample of 60 samples. The data 
analysis technique uses path analysis to test the magnitude of the contribution indicated by the path coefficient on each path diagram from the causal relationship of the variables $X 1, X 2, X 3$ to $Y 1, Y 2$. The results show an influence between word of mouth on tourist visit decisions, the effect of price on the decision of tourist visits, and the quality of service. In the joint test, the word of mouth, price, and service quality variables influence tourist visiting decisions. Meanwhile, several independent variables such as word of mouth, price, and service quality in the partial test affect the satisfaction variable. In the next test, the decision to visit affects tourist satisfaction.

Keywords: Price; Quality of Services; Satisfaction; Decision visits; Word of Mouth

\section{PENDAHULUAN}

Berkembangnya sektor pariwisata memerlukan partisipasi aktif segenap lapisan masyarakat dalam meningkatkan laju pembangunan nasional. Sektor pariwisata dapat menjadi penopang perekonomian rakyat dan menjadi salah satu sektor andalan untuk memperoleh devisa dan meningkatkan penerimaan pemerintah di luar minyak dan gas bumi. Untuk itulah perlu kiranya pemerintah pusat maupun pemerintah daerah membuat suatu kebijakan untuk meningkatkan perkembangan kepariwisataan dengan maksud untuk lebih mengembangkan ekonomi rakyat dan pencapaian hal-hal strategis antara pendapatan dan kesempatan kerja, mengembangkan potensi daerah, memanfaatkan sumber daya alam dan seni budaya, melalui sektor pariwisata. Tujuan penelitian ini adalah Untuk menganalisis pengaruh World of mouth, harga, kualitas layanan dan keputusan wisatawan mengunjungi Taman Margasatwa Ragunan serta mengetahui kepuasannya.

Salah satu obyek wisata yang populer dimasyarakat khususnya masyarakat ibukota yakni Taman Margasatwa Ragunan. Obyek wisata ini dikunjungi masyarakat baik dari Jakarta maupun sekitarnya terutama pada akhir pekan. Word of Mouth sebagai bentuk komunikasi dari mulut ke mulut dapat memberikan efek negatif bila tidak diantisipasi sebagai contoh berita mewabahnya virus flu burung beberapa waktu yang lalu dan pandemi covid 19 saat ini bila komunikasi tidak dijalankan dengan baik kepada wisatawan dapat berpengaruh terhadap tingkat kunjungan. Sedangkan berkaitan dengan harga tiket yang ditetapkan oleh pengelola terbilang rendah dan dapat dijangkau oleh sebagian besar masyarakat. Penetapan harga yang rendah memang suatu hal yang baik namun disisi lain ada yang perlu diperhatikan yakni kualitas layanan yang diberikan oleh pengelola dengan harga yang rendah tersebut. Kualitas yang baik merupakan suatu kewajiban bagi pengelola Taman Margasatwa Ragunan untuk memberikan pelayanan yang optimal meskipun dengan harga yang rendah. Kualitas layanan memang berkaitan dengan harga yang ditetapkan,karena dengan harga yang rendah maka tidak bisa memberikan kualitas yang baik, hal itulah yang menjadi hambatan dalam memberikan kualitas layanan yang baik kepada pengunjung. Pengelola harus tanggap terhadap permasalahan itu guna meningkatkan jumlah kunjungan dan dapat memberikan kepuasan kepada wisatawan.

Jurnal Ilmu Manajemen Sosial Humaniora (JIMSH), (4) 12022 Doi: $10.51454 /$ jimsh.v4i1.435 


\section{Word of Mouth (WOM)}

Menurut Kotler (2007) terdapat dua manfaat yang diperoleh dari komunikasi dari mulut ke mulut, yaitu:Komunikasi dari mulut ke mulut lebih meyakinkan dan Komunikasi dari mulut ke mulut tidak memerlukan biaya yang mahal. Pengetahuan konsumen terhadap produk dapat diperoleh dari hubungan komunikasi dari mulut ke mulut karena informasi yang diperoleh dari rekan dekat mudah dipercaya dibandingkan dari iklan.

Hasan (2008) mengatakan bahwa Word of mouth adalah sebuah bentuk tertua dari periklanan, dimana orang-orang yang memberikan informasi dan rekomendasi jujur kepada orang lain tentang merek, produk (barang atau jasa) dan layanan. Rose (2000) mengemukakan bahwa Word of mouth adalah keseluruhan komunikasi dari orang ke orang mengenai suatu produk, jasa atau perusahaan tertentu pada suatu waktu. Sernovitz (2009) mendefinisikan bahwa WOM Marketing adalah tindakan yang dapat memberikan alasan supaya semua orang lebih mudah dan lebih suka membicarakan produk kita.

\section{Harga}

Harga merupakan faktor yang dapat mempengaruhi konsumen dalam membeli suatu produk atau jasa yang diinginkan. Harga suatu barang atau jasa merupakan penentuan bagi permintaan pasar. Menurut Swastha (2008) harga merupakan jumlah uang yang dibutuhkan untuk mendapatkan sejumlah kombinasi dari produk dan pelayanannya. Menurut Keller (2013) harga adalah jumlah uang yang harus dibayarkan pelanggan untuk memperoleh produk. Sedangkan menurut Hasan (2008) konsep harga bagi konsumen adalah segala bentuk biaya moneter yang dikorbankan oleh konsumen untuk memperoleh, memiliki, memanfaatkan sejumlah kombinasi dari barang beserta pelayanan dari suatu produk. Bagi perusahaan, penetapan harga merupakan cara untuk membedakan penawarannya dari para pesaing.

\section{Kualitas Layanan}

Pelayanan menurut Parasuraman et.al yang dikutip oleh Lupiyoadi (2006) "bahwa service quality atau kualitas layanan dapat didefinisikan sebagai seberapa jauh perbedaan antara kenyataan dan harapan para nasabah atas layanan yang mereka terima atau peroleh". Kualitas layanan yang memuaskan akan memberikan gambaran yang baik terhadap perusahaan. Sebaliknya bila mengecewakan, kesan yang diterima nasabah akan buruk.

Menurut Keller (2013) definisi pelayanan adalah setiap tindakan atau kegiatan yang dapat ditawarkan oleh suatu pihak kepada pihak lain, yang pada dasarnya tidak berwujud dan tidak mengakibatkan kepemilikan apapun. Menurut Tjiptono (2015) kualitas pelayanan dapat diartikan sebagai upaya pemenuhan kebutuhan dan keinginan konsumen serta ketepatan penyampaiannya dalam mengimbangi harapan konsumen. 


\section{Keputusan Pembelian}

Menurut Swastha (2008) keputusan pembelian adalah pemahaman konsumen tentang keinginan dan kebutuhan akan suatu produk dengan menilai dari sumbersumber yang ada dengan menetapkan tujuan pembelian serta mengidentifikasi alternatif sehingga pengambil keputusan untuk membeli yang disertai dengan perilaku setelah melakukan pembelian. Sedangkan. Menurut Nugroho dan Agus (2003), keputusan pembelian adalah proses pengintegrasian yang mengkombinasi sikap pengetahuan untuk mengevaluasi dua atau lebih perilaku alternatif, dan memilih salah satu diantaranya. Pengambilan keputusan merupakan suatu kegiatan individu yang secara langsung terlibat dalam mendapatkan dan mempergunakan barang yang ditawarkan.

\section{Kepuasan Konsumen}

Kepuasan konsumen merupakan suatu respons positif seseorang terhadap suatu produk baik barang maupun jasa yang dirasakannya. Kepuasan konsumen didorong akan tuntutan konsumen terhadap kualitas akan produk dari waktu ke waktu. Kepuasan konsumen terjadi karena organisasi memfokuskan pada pelayanan dan kualitas yang diberikan. Kepuasan konsumen memberikan keuntungan yang diantaranya adalah bentuk kesetiaan konsumen maka organisasi harus berorentasi memuaskan kebutuhan konsumen. dalam hal ini jika gagal untuk memberikan kualitas yang dapat diterima maka organisasi tersebut akan kehilangan konsumen.

\section{METODE PENELITIAN}

Dalam melaksanakan penelitian ini, desain atau metode penelitian yang digunakan menggunakan metode survey, dan desain kausal menggunakan metode kausalitas. Metode survey merupakan penelitian yang diadakan untuk memperoleh fakta-fakta dari gejala-gejala yang ada dan mencari keterangan-keterangan secara faktual, baik tentang institusi sosial, ekonomi, dan politik dari suatu kelompok atau suatu daerah. Sedangkan metode kausalitas (Sugiono, 2011) adalah penelitian yang bertujuan untuk mengetahui hubungan antar dua variabel atau lebih, mencari peranan, pengaruh, hubungan yang bersifat sebab akibat yaitu antara variabel independent (variabel yang mempengaruhi) dan variabel dependent (variabel yang dipengaruhi). Teknik yang digunakan dalam penarikan sampel menggunakan nonprobability sampling yaitu teknik pengambilan sampel yang tidak memberi peluang/kesempatan yang sama bagi setiap unsur (anggota) populasi untuk dipilih menjadi anggota sampel. Salah satu teknik non -probability sampling yang digunakan dalam penelitian ini yakni menggunakan convenience sampling, teknik penentuan sampel ini berdasarkan kebetulan, yaitu siapa saja yang secara kebetulan bertemu dengan peneliti dapat digunakan sebagai sampel, bila dipandang orang yang kebetulan ditemui itu cocok sebagai sumber data (Sugiono, 2011). Atas dasar itulah maka sampel yang digunakan dalam penelitian ini berjumlah 60 sampel. 
Teknik Pengumpulan data dalam penelitian ini menggunakan penelitian kepustakaan (Library Research) Dalam penelitian ini penulis memperoleh data melalui berbagai literatur-literatur. Penelitian lapangan (Field Research) Dalam penelitian ini penulis mendatangi langsung objek yang diteliti untuk mendapatkan data-data yang dibutuhkan. Adapun metode yang digunakan dalam penelitian lapangan ini meliputi : Metode wawancara Pada metode ini dengan melakukan wawancara langsung terhadap pihak-pihak yang ada kaitannya dengan objek yang diteliti. Kuesioner dengan mengajukan seperangkat pertanyaan atau pernyataan teknis kepada responden untuk dijawab.

Teknik Analisis DataUji T Uji secara keseluruhan hipotesis statistik dirumuskan sebagai berikut: Membandingkan $t_{\text {critical dengan } t}$ hitung. Jika $t$ hitung $\geq t$ critical, maka $\mathrm{H}_{0}$ ditolak artinya signifikan dan apabila $\mathrm{t}$ hitung $\leq \mathrm{t}$ critical maka $\mathrm{H}_{0}$ diterima artinya tidak signifikan. Jika nilai probabilitas sig $<0.05$, maka $\mathrm{H}_{0}$ diterima dan $\mathrm{H}_{1}$ ditolak artinya signifikan. Apabila nilai probabilitas sig $>0.05$, maka $\mathrm{H}_{0}$ ditolak dan $\mathrm{H}_{1}$ diterima, artinya tidak signifikan. Uji $\mathrm{F}$ Untuk menguji keberartian dari koefisien regresi secara simultan, digunakan pengujian statistik uji F. Analisis Jalur Untuk menganalisis suatu hubungan sebab akibat pada regresi berganda yakni dimana bila variabel independen mempengaruhi variabel dependen tidak hanya secara langsung namun juga secara tidak langsung maka dapat digunakan analisa jalur.

\section{HASIL PENELITIAN DAN PEMBAHASAN}

\section{Hasil Penelitian}

Tabel 1. Hasil Uji Hipotesis Struktur 1

\begin{tabular}{|c|c|c|c|c|c|}
\hline \multirow[b]{2}{*}{ Model } & \multicolumn{2}{|c|}{$\begin{array}{l}\text { Unstandardized } \\
\text { Coefficients }\end{array}$} & \multirow{2}{*}{$\begin{array}{c}\begin{array}{c}\text { Standardized } \\
\text { Coefficients }\end{array} \\
\text { Beta }\end{array}$} & \multirow[b]{2}{*}{$\mathrm{T}$} & \multirow[b]{2}{*}{ Sig. } \\
\hline & B & Std. Error & & & \\
\hline 1 (Constant) & 1.026 & 1.193 & & .860 & .394 \\
\hline WOM & .173 & .075 & .221 & 2.306 & .025 \\
\hline HARGA & .495 & .077 & .527 & 6.440 & .000 \\
\hline KUALITAS_PELAYANAN & .307 & .106 & .262 & 2.890 & .005 \\
\hline
\end{tabular}

a. Dependent Variable: KEPUTUSAN_KUNJUNGAN

Tabel 1 menunjukkan terdapat pengaruh antara word of mouth terhadap keputusan kunjunganwisatawan diTaman Margasatwa ragunan. Hal ini ditunjukkan dengan nilai t hitung 2,306 $>\mathrm{t}$ critical 2,003. Terdapat pengaruh antara harga terhadap keputusan kunjungan wisatawan diTaman Margasatwa ragunan. Hal ini ditunjukkan dengan nilai t hitung $6,440>t$ critical 2,003. Terdapat pengaruh antara kualitas layanan terhadap keputusan kunjungan wisatawan di Taman Margasatwa ragunan. Hal ini ditunjukkan dengan nilai t hitung 2,890 $>\mathrm{t}$ critical 2,003. 
Tabel 2 Hasil Uji Hipotesis Struktur II cefficients $^{\mathrm{a}}$

\begin{tabular}{|c|c|c|c|c|c|}
\hline \multirow[b]{2}{*}{ Model } & \multicolumn{2}{|c|}{$\begin{array}{c}\text { Unstandardized } \\
\text { Coefficients }\end{array}$} & \multirow{2}{*}{$\begin{array}{c}\begin{array}{c}\text { Standardized } \\
\text { Coefficients }\end{array} \\
\text { Beta }\end{array}$} & \multirow[b]{2}{*}{$\mathrm{T}$} & \multirow[b]{2}{*}{ Sig. } \\
\hline & B & Std. Error & & & \\
\hline 1 (Constant) & 5.517 & 1.482 & & 3.721 & .000 \\
\hline WOM & .284 & .097 & .271 & 2.928 & .005 \\
\hline HARGA & .272 & .125 & .216 & 2.174 & .034 \\
\hline KUALITAS_PELAYANAN & .359 & .141 & .229 & 2.553 & .013 \\
\hline KEPUTUSAN_KUNJUNGAN & .409 & .165 & .306 & 2.482 & .016 \\
\hline
\end{tabular}
a. Dependent Variable: KEPUASAN

1) Terdapat pengaruh antara word of mouth terhadap kepuasan pengunjung di Taman Margasatwa Ragunan. Hal ini ditunjukkan dengan nilai t hitung 2,928 > $t$ critical 2,004.

2) Terdapat pengaruh antara harga terhadap kepuasan pengunjung wisatawan di Taman Margasatwa Ragunan. Hal ini ditunjukkan dengan nilai t hitung 2,174 >t critical 2,004.

3) Terdapat pengaruh antara kualitas layanan terhadap kepuasan pengunjung wisatawan di Taman Margasatwa Ragunan. Hal ini ditunjukkan dengan nilai t hitung 2,553 >t critical 2,004.

4) Terdapat pengaruh antara keputusan kunjungan wisatawan terhadap kepuasan mengunjungi Taman Margasatwa Ragunan. Hal ini ditunjukkan dengan nilai $\mathrm{t}$ hitung 2,482 $>\mathrm{t}$ critical 2,004.

5) Terdapat pengaruh antara word of mouth, harga, kualitas layanan terhadap keputusan kunjungan wisatawan di Taman Margasatwa ragunan. Hal ini ditunjukkan dengan nilai $\mathrm{F}$ hitung 72,637 > F tabel 2,679.

Tabel 3 Hasil Uji F

\begin{tabular}{|c|c|c|c|c|c|c|}
\hline & Model & $\begin{array}{l}\text { Sum of } \\
\text { Squares }\end{array}$ & $\mathrm{df}$ & Mean Square & $\mathrm{F}$ & Sig. \\
\hline \multirow[t]{3}{*}{1} & Regression & 471.750 & 3 & 157.250 & 72.637 & $.000^{\mathrm{a}}$ \\
\hline & Residual & 121.233 & 56 & 2.165 & & \\
\hline & Total & 592.983 & 59 & & & \\
\hline
\end{tabular}

a. Predictors: (Constant), KUALITAS_PELAYANAN, HARGA, WOM

b. Dependent Variable: KEPUTUSAN_KUNJUNGAN 
Pengaruh langsung (Direct Effect (DI))

Pengaruh dari $X_{1}, X_{2}, X_{3}$ terhadap $Y_{1}$ dan $Y_{1}$ terhadap $Y_{2}$ dapat disajikan seperti beriku ini :

$$
\begin{array}{lrl}
\mathrm{X}_{1} \rightarrow \mathrm{Y}_{1} ; & \rho_{y 1 x 1}=0,221 \\
\mathrm{X}_{2} \rightarrow \mathrm{Y}_{1} ; & \rho_{y 1 \times 2}=0,527 \\
\mathrm{X}_{3} \rightarrow \mathrm{Y}_{1} ; & \rho_{y 1 x 3}=0,262 \\
\mathrm{Y}_{1} \rightarrow \mathrm{Y}_{2} ; & \rho_{y 2 y 1}=0,306
\end{array}
$$

Pengaruh tidak langsung (Indirect Effect (IE))

Pengaruh tidak langsung ini merupakan pengaruh dari $X_{1}$ ke $Y_{2}$ melalui $Y_{1}$, pengaruh dari $X_{2}$ ke $Y_{2}$ melalui $Y_{1}$ dan pengaruh dari $X_{3}$ ke $Y_{2}$ melalui $Y_{1}$. Penulisannya dapat disajikan sebagai berikut:

$$
\begin{array}{ll}
\mathrm{X} 1 \rightarrow \mathrm{Y} 1 \rightarrow \mathrm{Y} 2 ; & \rho_{y 1 x 1} \cdot \rho_{y 2 y 1}=(0,221)(0,306)=0,067 \\
\mathrm{X} 2 \rightarrow \mathrm{Y} 1 \rightarrow \mathrm{Y} 2 ; & \rho_{y 1 x 2} \cdot \rho_{y 2 y 1}=(0,527)(0,306)=0,161 \\
\mathrm{X} 3 \rightarrow \mathrm{Y} 1 \rightarrow \mathrm{Y} 2 ; & \rho_{y 1 x 3} \cdot \rho_{y 2 y 1}=(0,229)(0,306)=0,070
\end{array}
$$

Pengaruh total (Total Effect (TE))

Pengaruh total adalah penjumlahan DE dan IE perhitungannya adalah sebagai berikut:

$$
\begin{aligned}
& T E_{11}=D E y_{1} x_{1}+I E y_{2} y_{1} x_{1}=0,221+0,067=0,288 \\
& T E_{12}=D E y_{1} x_{2}+I E y_{2} y_{1} x_{2}=0,527+0,161=0,688 \\
& T E_{13}=D y_{1} x_{3}+I E y_{2} y_{1} x_{3}=0,229+0,070=0,299 \\
& T E_{21} D E y_{2} y_{1}=0,306
\end{aligned}
$$

\section{PEMBAHASAN}

Word of mouth memiliki pengaruh terhadap keputusan kunjungan wisatawan diTaman Margasatwa Ragunan. Hal ini mendukung penelitian sebelumnya (Atikah, 2020) yang menyatakan word of mouth memiliki pengaruh positif yang signifikan terhadap keputusan kunjungan wisatawan di Keraton Yogyakarta. Pengaruh Word of mouth terlihat dari dikenalnya wisata Taman Margasatwa Ragunan secara luas sehingga wisatawan tidak ragu berkunjung. Terdapat pengaruh antara harga terhadap keputusan kunjungan wisatawan diTaman Margasatwa Ragunan. Hal ini menunjukkan bahwa ada pengaruh yang signifikan antara harga terhadap keputusan kunjungan. Hasil penelitian ini mendukung penelitian sebelumnya (Rahmadayanti \& Murtadlo, 2020) yakni harga berpengaruh terhadap keputusan kunjungan wisatawan pada obyek di Curug Goa Jalmo Kabupaten Pasuruan.

Sementara itu, kualitas layanan memiliki pengaruh terhadap keputusan kunjungan wisatawan di Taman Margasatwa Ragunan. Artinya kualitas layanan akan berpengaruh signifikan terhadap keputusan kunjungan. Penelitian ini mendukung hasil penelitian sebelumnya oleh Simarmata \& Yunus (2021) yang mengambil obyek 
pada wisata danau toba. Pengaruh positif yang ditimbulkan memiliki makna bahwa semakin baik kualitas layanan yang diberikan maka akan mendorong wisatawan memutuskan kunjungan kembali atau merekomendasikan kepada orang lain.

Word of mouth memiliki pengaruh terhadap kepuasan pengunjung di Taman Margasatwa Ragunan. Hal mendukung dengan penelitian sebelumnya oleh Rosifa, dkk. (2020) dimana Word of mouth berpengaruh terhadap kepuasan pengunjung di New Marjoly Beach And Resort. Word of mouth memiliki andil di dalam terbentuknya kepuasan pengunjung di taman Margasatwa Ragunan. Adanya word of mouth terkait dengan kepuasan pengunjung. Terdapat pengaruh antara harga terhadap kepuasan pengunjung wisatawan di Taman Margasatwa Ragunan. Hasil penelitian ini mendukung penelitian sebelumnya oleh Widyastuti (2017) dimana harga berpengaruh terhadap kepuasan pengunjung wisatawan Artinya secara langsung harga yang ditawarkan dapat menjadikan pengunjung merasa puas. Kepuasan ini dapat disebabkan oleh kesesuaian antara biaya yang dikeluarkan dengan hasil yang diperoleh.

Kualitas layanan memiliki pengaruh terhadap kepuasan pengunjung wisatawan di Taman Margasatwa Ragunan. Artinya kualitas layanan yang memuaskan tentunya akan berdampak langsung terhadap kepuasan pengunjung. Pengunjung merasa puas jika mendapatkan layanan yang memuaskan. Hasil penelitian ini mendukung penelitian sebelumnya oleh Nanincova (2019) yang melakukan penelitian pada pelanggan Noach Cafe and Bistro dimana Kualitas layanan berpengaruh terhadap kepuasan pengunjung. Terdapat pengaruh antara keputusan kunjungan wisatawan terhadap kepuasan mengunjungi Taman Margasatwa Ragunan. Hasil ini mendukung Penelitian sebelumnya oleh Kristiutami (2017) juga mengungkapkan hasil yang sama bahwa keputusan kunjungan berpengaruh positif dan signifikan terhadap kepuasan wisatawan. Pengunjung yang telah memutuskan untuk mengunjungi taman Margasatwa Ragunan akan dapat menilai tempat tersebut. Penilaian pengunjung ini berdampak langsung terhadap kepuasan mengunjungi.

Word of mouth, harga dan kualitas layanan berpengaruh terhadap keputusan kunjungan wisatawan di Taman Margasatwa Ragunan. Hasil penelitian ini mendukung penelitian sebelumnya oleh Saifullah, dkk.(2019); Rumondor, dkk. (2017). Artinya ketiga variabel tersebut word of mouth, harga dan kualitas layanan berpengaruh terhadap keputusan kunjungan. Pengaruh yang ditimbulkan secara serentak dari ketiga faktor tersebut terhadap keputusan kunjungan wisatawan termasuk dalam kategori korelasi yang kuat.

\section{SIMPULAN}

Pengaruh word of mouth terhadap keputusan kunjungan sebesar 0,221 korelasi variabel 0,755 atau korelasi kuat. Pengaruh harga terhadap keputusan kunjungan sebesar 0,527 korelasi variabel 0,827 atau sangat kuat. Pengaruh kualitas layanan terhadap keputusan kunjungan sebesar 0,262 korelasi variabel 0,736 atau kuat. Pengaruh word of mouth terhadap kepuasan pengunjung sebesar 0,271 korelasi 
variabel 0,810 atau sangat kuat. Pengaruh harga terhadap kepuasan pengunjung sebesar 0,216 korelasi variabel 0,782 atau kuat. Pengaruh kualitas layanan terhadap kepuasan pengunjung, pengaruh langsung sebesar 0,229 dan pengaruh tidak langsung 0,070. Pengaruh ini lebih kecil dari pengaruh langsung dengan korelasi variabel 0,780 atau korelasi kuat. Pengaruh keputusan kunjungan terhadap kepuasan mengunjungi ke Margasatwa Ragunan sebesar 0,306 korelasi variabel 0,858 atau sangat kuat. Pengaruh word of mouth, harga, kualitas layanan terhadap keputusan kunjungan Pengaruh variabel itu secara simultan ke keputusan kunjungan sebesar 0,796 dengan korelasi variabel 0,892 atau sangat kuat.

\section{UCAPAN TERIMAKASIH}

Penulis mengucapkan terimakasih kepada seluruh pihak yang telah membantu hingga selesainya artikel ini, khususnya kepada editorial JIMSH, LPPM Universitas Muhammadiyah Kendari dan reviewer yang telah memberikan kesempatan penulis untuk mempublikasikan artikel ini serta memberikan masukan guna perbaikan tulisan ini.

\section{DAFTAR PUSTAKA}

Atikah, H. J. (2020). Pengaruh Electronic Word Of Mouth Terhadap Keputusan Kunjungan Wisatawan di Keraton Yogyakarta HANA JIHAN ATIKAH, Dra. Neni Pancawati, M.Si. http://etd.repository.ugm.ac.id/penelitian/detail/189943

Hasan, A. (2008). Marketing. MedPress.

Keller, K. (2013). MANAJEMEN PEMASARAN (2nd ed.). Erlangga.

Kotler, P. dan K. L. K. (2007). Manajemen Pemasaran (12th ed.). Indeks.

Kristiutami, Y. P. (2017). Pengaruh Bauran Pemasaran Terhadap Keputusan Berkunjung Wisatawan Di Museum Geologi Bandung. Jurnal Pariwisata, 4(2), 53-62. http://ejournal.bsi.ac.id/ejurnal/index.php/jp

Lupiyoadi. (2006). Manajemen Pemasaran Jasa (2nd ed.). Salemba Empat.

Niken Nanincova. (2019). Pengaruh Kualitas Layanan Terhadap Kepuasan Pelanggang Noach Cafe and Bistro. Agora, 7(2), 1-5.

Nugroho dan Aloisius Agus. (2003). Multikulturalisme dalam sinis. Grasindo.

Rose, E. (2000). Kiat Pemasaran dari Mulut ke Mulut (The Anatomy of Buzz). PT.Elex Komputindo.

Rosifa, A., Suprihartini, L., \& Kurniawan, R. (2020). Pengaruh Nilai Pelanggan Dan Electronic Word Of Mouth Terhadap Kepuasan Pengunjung Dengan Keputusan Berkunjung Sebagai Variabel Intervening Pada New Marjoly Beach And Resort. Bahtera Inovasi, 4(1), 64-76. https://doi.org/10.31629/bi.v4i1.2759

Rumondor, P., Tumbel, A., \& Ogi, I. (2017). Pengaruh Kualitas Produk, Harga, Dan Word of Mouth Terhadap Keputusan Pembelian Pada Rumah Kopi Dan Mie Toronata Di Kawangkoan. Jurnal Riset Ekonomi, Manajemen, Bisnis Dan Akuntansi, 5(2), 1102-1112. https://doi.org/10.35794/emba.v5i2.16084

Saifullah, M., Rachma, N., \& Khoirul, M. (2019). Analisis Pengaruh Word of Mouth, 
Kualitas Layanan, Kualitas Produk, dan Lokasi terhadap Keputusan Pembelian Konsumen (Studi Kasus pada Toko Bandung Super Model Dinoyo Malang). EJurnal Riset Manajemen Prodi Manajemen, 8(2007), 25-41.

Sernovitz, A. (2009). Word of mouth Marketing. Kaplan Inc.

Simarmata, P. P., \& Yunus, M. (2021). PENGARUH KUALITAS LAYANAN TERHADAP

KEPUTUSAN KUNJUNGAN WISATA KE DANAU TOBA SELAMA PANDEMI COVID19. 4, 460-468. https://doi.org/10.37600/ekbi.v4i2.313

Sugiono. (2011). Statistika untuk Penelitian. Alfabeta.

Swastha, B. \& I. (2008). Menejemen Pemasaran Modern (7th ed.). LIBERTY.

Tina Rahmadayanti, \& Kholid Murtadlo. (2020). Pengaruh Efektivitas Media Sosial, Daya Tarik, Harga Tiket, dan Fasilitas Pelayanan Wisata Terhadap Keputusan Berkunjung di Curug Goa Jalmo Kabupaten Pasuruan. Malia (Terakreditasi), 12(1), 125-136. https://doi.org/10.35891/ml.v12i1.2392

Tjiptono, F. (2015). Strategi Pemasaran (4th ed.). Andi.

Widyastuti, T. (2017). Pengaruh Harga dan Kualitas Produk Terhadap Kepuasan Pelanggan Tempe. Jurnal Ekonomi, Manajemen, Dan Bisnis, 1(2), 233-240. http://ejournal.bsi.ac.id/ejurnal/index.php/ecodemica/article/view/2130 